DOI: $10.14746 /$ por.2019.1.23

\title{
DZIEDZICTWA I ZOMBIE. DLACZEGO NALEŻY WSPIERAĆ KRÓTKOTERMINOWE PROGNOZY ANALIZĄ ZJAWISK DŁUGOFALOWYCH
}

\author{
Greg Grzegorz Lewicki ${ }^{1}$ \\ (Polski Instytut Ekonomiczny)
}

\begin{abstract}
Słowa kluczowe: posttotalitaryzm, transformacja postkomunistyczna, longue durée, Aviezer Tucker, The Legacies of Totalitarnianism

Keywords: post-totalitarianism, post-communist transformation, longue durée, Aviezer Tucker, The Legacies of Totalitarianism
\end{abstract}

\begin{abstract}
Abstrakt: Greg Grzegorz Lewicki, DZIEDZICTWA I ZOMBIE. DLACZEGO NALEŻY WSPIERAĆ KRÓTKOTERMINOWE PROGNOZY ANALIZĄ ZJAWISK DŁUGOFALOWYCH. „PORÓWNANIA" 1 (24), 2019. T. XXIV, S. 269-273. ISSN 1733-165X. Autor stwierdza, że praca Tuckera The Legacies of Totalitarnianism jest niezmiernie ważna dla studiów nad postkomunizmem w Europie Środkowej i Wschodniej oraz dla historiozofii, która od czasów poheglowskich stroniła od holizmu. Zdaniem autora, Tucker trafnie identyfikuje ponadnarodowe składowe wspólnej tożsamości regionu, wynikające z tytułowych "dziedzictw” (procesów średnioterminowych wywodzących się z komunizmu). Badacz zauważa jednak, że nietrafność części prognoz Tuckera na podstawie jego własnej teorii wynika $\mathrm{z}$ nieuwzględnienia pewnych prawideł socjopsychologicznych i procesów długoterminowych.
\end{abstract}

\begin{abstract}
Greg Grzegorz Lewicki, LEGACIES AND ZOMBIE. WHY YOU SHOULD SUPPORT SHORT-TERM PROGNOSES WITH THE ANALYSIS OF LONG-TERM PHENOMENA. "PORÓWNANIA" 1 (24), 2019. Vol. XXIV, P. 269-273. ISSN 1733-165X. The author claims that Tucker's "Legacies of Totalitarianism" is extremely important for the studies of post-communism in Central and Eastern Europe as well as for philosophy of history, which - from the post-Hegelian times on - has avoided holistic approaches. According to the author, Tucker adequately identifies transnational components of the region's current identity, rooted in the abovementioned "legacies" (middle-range processes that started in the communist era). The author also notes that
\end{abstract}

1 E-mail: greglewicki@alumni.lse.ac.uk 
inadequacy of some prognoses that Tucker puts forward based on his own theory stems from his negligence of the prognostic weight of certain socio-psychological laws and long-term processes.

W swojej pracy na temat posttotalitaryzmu Aviezer Tucker z powodzeniem konstruuje teorię ogólną, którą można dalej rozwijać i stosować w celu zrozumienia stanu wielu społeczeństw posttotalitarnych - i to niezależnie od dzielących je różnic rozwojowych, politycznych, geograficznych czy historycznych, a nawet gospodarczych. Jak się wydaje, wysoko ponad całą różnorodnością dziejową Europy Środkowej i Wschodniej po 1989 roku można znaleźć cały szereg czynników ujednolicających, wywodzących się ze wspólnych strasznych historycznych doświadczeń państw regionu. Są nimi posttotalitarne dziedzictwa tych państw (definiowane przez Tuckera jako procesy o średnim okresie trwania (Tucker 6)).

Autor zauważa, że dotychczas nikomu nie udało się stworzyć spójnej teorii doświadczenia społeczeństw posttotalitarnych, a badacze, którzy podjęli taką próbę, pomijali często ważne treści filozoficzne i polityczno-teoretyczne z pism dysydentów europejskich. W rezultacie głębsze znaczenie wydarzeń z lat 1989-1991 unosiło się w "filozoficznej pustce", częściowo tylko wypełnianej przez prace zawierające "ahistoryczny błąd intelektualny”. Błąd ten polegał na zakładaniu, że każde społeczeństwo wyzwolone z tyrańskiego reżimu, jeśli tylko minie wystarczający czas, osiągnie stan dojrzałej demokracji liberalnej w zachodnim stylu - niezależnie od jego kultury, struktury czy historii (Tucker 2-12).

Tucker dowodzi naiwności takiego sposobu myślenia. Nie tylko odkrywa złożone czynniki wpływające na różnorodność ścieżek prowadzących państwa Europy Środkowej i Wschodniej do demokracji, lecz także pokazuje, iż takim przekształceniom ustrojowym daleko jest do modelowej, dualistycznej zamiany jednej postaci rządu na drugą. Stosując myślenie charakterystyczne dla logiki rozmytej, Tucker sugeruje, że istnieje całe spektrum pośrednich "form” rządu, rozciągające się pomiędzy wyidealizowanymi biegunami totalitaryzmu i demokracji, które powstają na skutek różnic kulturowych i społecznych pomiędzy państwami. Dlatego podkreśla nieoczywistą naturę przejścia do demokracji i skutecznie wykazuje, że organiczne pozostałości nowotworu komunistycznego mogą wrosnąć w zdrową tkankę demokratyczną i utrzymywać się w niej, a w efekcie zwiększać ryzyko wystąpienia patologicznych mechanizmów społecznych już w nominalnych demokracjach.

Dokładniej rzecz ujmując, zdaniem Tuckera państwa Europy Środkowej i Wschodniej zmagają się z dziedzictwem poprzedniej epoki. Są to takie zjawiska, jak zacofanie gospodarcze (Tucker 14-15), ", niedopracowany system sprawiedliwości" (ang. rough justice) - czyli taki, który nie osiągnął pożądanego przez ogół społeczeństwa poziomu przejrzystości i uczciwości (Tucker 73-74), czy też zakulisowy wpływ elity posttotalitarnej (której celem było przekształcenie dotychczasowych swobód w prawa własności, a dzięki temu utworzenie odrębnej klasy społecznej) (Tucker 22, 33-37). 
To ważne, bo wpływ tych czynników na region niejednokrotnie umniejszano. Ze swojego doświadczenia w pracy dziennikarza i eksperta do spraw prognostyki wnoszę, że wielu intelektualistów, polityków i specjalistów wciąż jeszcze nie uznaje ich za istotne zmienne mające wpływ na region Europy Środkowej i Wschodniej. Wymownym dowodem tego stanu rzeczy jest zdumienie części elit w niektórych krajach i w organach Unii Europejskiej na wieść o ogłoszeniu przez polską partię prawicową Prawo i Sprawiedliwość planu reformy systemu sądowniczego po wyborach w 2015 roku (Rankin). Abstrahując od kontrowersji wzbudzanych przez tę reformę, należy zauważyć, że potrzebę gruntownej naprawy systemu sądownictwa dostrzegano od wielu dziesięcioleci. Wspominali o niej członkowie polskich elit, w tym lewicowy prezydent Aleksander Kwaśniewski (1995-2005) czy koordynator służb specjalnych Bartłomiej Sienkiewicz (2013-2014) wywodzący się z centrystycznych środowisk politycznych. Pożądane zmiany nie zostały jednak w pełni wprowadzone, ponieważ w pierwszych dekadach demokracji po 1989 roku elity rządzące Polską pozostawały w przekonaniu, że nie należy narażać się na oskarżenia o zbyt intensywne zabiegi wokół systemu sądowniczego, bo mogłoby to naruszać pozytywny obraz kraju jako przestrzegającego wszystkich standardów europejskich. Dziś jednak temat dziedzictwa totalitarnego rozumianego jako brak reformy „niedopracowanego" systemu sądowniczego powraca. To powrót w formie swoistego "politycznego zombie" - to, co zostało niegdyś przedwcześnie pochowane do grobu, teraz wraca jako zmora.

Kolejnym dowodem na słuszność przekonań Tuckera o utrzymującym się wpływie powyższych czynników na państwa Europy Środkowej i Wschodniej oraz ich politykę jest to, że w ostatnim czasie zacofanie gospodarcze Polski zaczęło mocniej irytować opinię publiczną (TNS Polska). Dlaczego dopiero teraz? Ponieważ w okresie transformacji (postrzeganej przez Polaków jako okres wyjątkowy dziejowo, a wiec wymagający poświęceń) potrzeby dobrobytu były świadomie tłumione. Jednak od niedawna, dzięki udanemu powiązaniu Polski z Unią Europejską (a w szczególności z Niemcami), to podejście się zmieniło: potrzeby gospodarcze Polaków kształtowane są teraz przez odniesienie do warunków gospodarczych w bogatszych krajach zachodnich. Z punktu widzenia koncepcji Tuckera można tę sprawę ująć następująco: oto w polskich stosunkach wewnętrznych nabrało politycznej wagi kolejne dziedzictwo posttotalitarne, a mianowicie nieznośna świadomość przepaści gospodarczej pomiędzy Polską a krajami Zachodu, wynikającej z posttotalitarnego zacofania.

Skala zgodności modelu Tuckera z aktualnym krajobrazem spraw publicznych w Europie Środkowej i Wschodniej dowodzi jego ogólnej adekwatności i bardzo wysokiej przydatności naukowej. W rzeczy samej, poza kilkoma drobnymi potknięciami (jak na przykład twierdzeniem, że filozofia historii Oswalda Spenglera jest linearna) (Tucker 11), część teoretyczna omawianej książki jest wyśmienita.

Słabych stron można się jednak dopatrzeć pod koniec dzieła, w rozdziałach szóstym i siódmym, w których autor podejmuje próbę przewidzenia przyszłości Eu- 
ropy na podstawie swojej teorii. Po pierwsze, na przykład w eseistycznych rozważaniach o edukacji wyraz "totalitarny" wydaje się być mylony czasem z terminem "autorytarny”, a nawet „skorumpowany". Choć Tucker zasadnie stygmatyzuje korupcję w systemie uczelnianym, wątpliwe jest, by stwarzała ona ryzyko przywrócenia totalitaryzmu tylnymi drzwiami. Z całą pewnością, jeśli państwa Europy Środkowej i Wschodniej faktycznie poszłyby śladami tureckiego prezydenta Recepa Tayyipa Erdoğana (który zwolnił tysiące pracowników naukowych pod pretekstem, że są politycznie „podejrzani”), przewidywania Tuckera okazałyby się trafne (Weise, Ensor). Jeśli jednak uczelnie tego regionu pozostaną po prostu trybami przeciętnego systemu edukacji, zmagając się z takimi problemami, jak korupcja i złe zarządzanie, to - odwołując się do terminologii Immanuela Wallersteina - będziemy mieli do czynienia raczej ze zwykłym przypadkiem systemu akademickiego (pół) peryferiów.

Podobne problemy sprawia autorowi interpretacja nieliberalnych trendów w krajach Europy Środkowej i Wschodniej, które można by uznać co najwyżej za autorytarne, lecz nie totalitarne. Wbrew nadziejom Tuckera, czas pokazał, że tych tendencji nie dało się ot tak, po prostu „strząsnąć" z tkanki społecznej. Dlaczego tak jest? Może to mieć związek nie tylko z dziedzictwami o średnim okresie oddziaływania, ale też z długoterminowymi zjawiskami opisanymi przez Fernanda Braudela, o których istnieniu Tucker zaledwie wspomina w swoim dziele (Tucker 6). W przypadku Europy Środkowej i Wschodniej do zjawisk longue durée zaliczyć należy między innymi niewystępowanie silnie obciążającej moralnie traumy bycia kolonizatorem, co ma dziś wpływ na podejście w tym regionie do tematów migracji i akulturacji ${ }^{2}$, a także doświadczenie wielu stuleci słabości instytucjonalnej szereg państw tego regionu przeżyło całkowity lub częściowy upadek po okresie świetności (definiowanej wedle własnych kryteriów), a trauma ta do dziś odciska piętno na stosunku obywateli do idei silnego rządu. Można dodać do tych czynników rzeczy takie jak międzynarodowa destabilizacja związana z zachwianiem jednobiegunowego świata kontrolowanego przez Stany Zjednoczone (Arak, Lewicki 2017); wielka, rozbrajająca stabilność Europy migracja z Afryki i Bliskiego Wchodu (Arak, Lewicki 2018), korelacja Jonathana Haidta pomiędzy popularnością partii prawicowych a poczuciem braku stabilności przez obywateli (Haidt) czy wreszcie niemarksowska dynamika klasowa Leszka Nowaka w wydaniu demokratycznym (Brzechczyn 2003; 2016). Biorąc pod uwagę powyższe czynniki, można przewidywać i objaśniać trendy w Europie Środkowo-Wschodniej lepiej niż na podstawie samego tylko odniesienia do posttotalitaryzmu.

Zamiast podsumowania pozwolę sobie przytoczyć myśl Christophera Cokera, który stwierdził, że choć nie powinniśmy żałować końca holistycznej ery heglow-

2 Choć niektórzy badacze twierdzą, że państwa Europy Środkowej i Wschodniej kolonizowały w swojej historii sąsiadów (Sowa), skala tego zjawiska była nieporównywalna do kolonialnych podbojów krajów zachodnioeuropejskich. 
skiej, to jednak niestety nie stworzyliśmy żadnej alternatywy mogącej posłużyć do interpretowania procesów dziejowych (Coker 18). Książki Tuckera przełamują tę filozoficzno-historyczną inercję i stanowią śmiały powrót do holizmu. Daleki od heglizmu Tucker odkrywa na nowo interdyscyplinarną filozofię historii, ukazując, że w kulturach posttotalitarnych można wyodrębnić zestaw obiektywnych zmiennych formatywnych, które pełnią rolę czynników objaśniających, przyczynowych i współtworzących tożsamość państw Europy Środkowej i Wschodniej - niezależnie od różnic kulturowych pomiędzy nimi.

Tę ulotną wspólnotę obywateli Europy Środkowej i Wschodniej można uchwycić, przedstawiając reakcje na dowcip popularny w czasach komunistycznych: „Dlaczego Rosjanie to nasi bracia?” „Bo rodziny się nie wybiera”. Dziś, słysząc ten kawał, mieszkańcy państw posttotalitarnych będący w średnim wieku zwykle od razu wybuchają śmiechem, podczas gdy starszych czy młodszych żart ten albo nie śmieszy, albo go nie rozumieją. W swojej wyjątkowej książce Tucker pomaga zrozumieć te właśnie warstwy doświadczeń, ideałów, przekonań i obaw w głowie tych, którzy się śmieją, identyfikuje też mechanizmy o średniej trwałości, które działają gdzieś w tle życia obywateli społeczeństw posttotalitarnych.

\section{BIBLIOGRAFIA}

Arak Piotr, Lewicki Grzegorz. „Migracje, wojny oraz inne plagi międzyepoki”. Indeks Mocy Państw 2018. Instytut In.Europa. 2018. Web. 19.06.2019. <http://ineuropa.pl/2018/wyniki-globalne/migracje-wojny/>

Arak Piotr, Lewicki Grzegorz. „China catching up with the US”. State Power Index 2017. Instytut In.Europa. 2017. Web. 09.06.2019. <www.statepowerindex.com>

Brzechczyn, Krzysztof. „Polska - deKODowanie systemu”. Arcana. Kultura - Historia - Polityka 127-128 (2016). S. 34-48.

Brzechczyn Krzysztof, red. Ścieżki transformacji. Ujęcia teoretyczne i opisy empiryczne. Poznań: Zysk i S-ka, 2003.

Coker, Christopher. Twilight of the West. Oxford: Basic Books, 1998.

Haidt, Jonathan. The Righteous Mind: Why Good People Are Divided by Politics and Religion. Nowy Jork: Vintage, 2012.

Rankin, Jennifer. „Poland's changes to court system 'endanger democracy'”. The Guardian, 29.02.2016.

Sowa, Jan. Fantomowe ciało króla. Warszawa: Universitas, 2011.

Tucker, Aviezer. The Legacies of Totalitarianism. A Theoretical Framework. Cambridge: Cambridge University Press, 2015.

TNS Polska. „Polacy niezadowoleni z sytuacji ekonomicznej w kraju”. Newsweek.pl, 25.07.2013.

Weise Zia, Ensor Josie. „Turkey fires 21,000 teachers and demands suspension of every university dean in post-coup crackdown". Telegraph.co.uk, 19.07.2016. 
